\title{
BIOLOGICAL PROTECTION OF CONIFERS AGAINST HETEROBASIDION INFECTION - INTERACTION BETWEEN ROOT-ROT FUNGUS AND PHLEBIOPSIS GIGANTEA
}

\author{
Kristīne Kenigsvalde' ${ }^{1}$, Indulis Brauners ${ }^{2}$, Astra Zaḷuma ${ }^{1}$, Jurğis Jansons ${ }^{1}$, Tālis Gaitnieks ${ }^{1}$ \\ ${ }^{1}$ Latvian State Forest Research Institute 'Silava' \\ ${ }^{2}$ JSC 'Latvia's State Forests' \\ talis.gaitnieks@silava.lv
}

\begin{abstract}
The biological control agent Rotstop, composed of spores of Phlebiopsis gigantea, is used for treatment of conifer stumps to reduce the spread of Heterobasidion root rot in commercial forests. Two experiments were conducted to compare the antagonistic ability of the Rotstop isolate and nine Latvian isolates of $P$. gigantea against root rot fungus Heterobasidion, in wood of Scots pine and Norway spruce. Billets of conifer trees were first sprayed with a spore suspension of $P$. gigantea and then with Heterobasidion at different concentrations. The presence of fungi in billets was evaluated by morphological characteristics of mycelium. The Latvian isolates of $P$. gigantea showed similar or even higher values of efficacy against Heterobasidion (average efficacy $84 \%$ in spruce and $89 \%$ in pine) than the commercially manufactured Finnish preparation Rotstop (61\% in spruce and $90 \%$ in pine). Latvian isolates of $P$. gigantea have a potential to be used for preparation of biological control agents in the future.
\end{abstract}

Key words: biological control, Norway spruce, Scots pine, Heterobasidion, Phlebiopsis gigantean.

\section{Introduction}

Annual economic losses caused by Heterobasidion root rot in the European Union comprise ca. 500 million euros (Korhonen \& Holdenrieder, 2005). In southern Finland annual financial losses in coniferous stands have been estimated to be around 35 million euros (Bendz-Hellgren et al., 1998). In Latvia, Gaitnieks et al. (2008) reported that losses due to root rot in final felling of spruce stands were 800-4790 euros per hectare, depending on timber yield and infection frequency in the stand. As stands of spruce comprise 584 thousand ha $(18.27 \%)$ of the total forest area of Latvia (Jansons, 2014), losses caused by root rot in spruce stands are considerable. Calculations made in Latvian State Forest Research Institute 'Silava' show that total losses caused by root rot in spruce forests of Latvia are at least 7 million euros annually (unpublished data). Heterobasidion root rot causes considerable economic losses also in Scots pine stands, especially in young stands. In Lithuania, Heterobasidion root rot was present in 53\% of surveyed young stands of pine (Василяускас, 1989).

Spores of Heterobasidion infect fresh conifer stumps and wounds of growing conifers (primary infection). Mycelium of the fungus spreads along roots and moves from tree to tree via root contacts (secondary spread). Primary infection initiates development of new disease centres in stands where infection was not present before. Fresh conifer stumps cut during logging are the main source of Heterobasidion infection, but if growth conditions are favourable for spores, wounded roots in the soil can be infected as well (Redfern \& Stenlid, 1998; Stenlid $\&$ Redfern, 1998). Sporulation of Heterobasidion in Northern countries and Latvia reaches its maximum in summer and autumn (Yde-Andersen, 1962; Kallio,
1970; Brandtberg, Johansson, \& Seeger, 1996; Brūna, Gaitnieks, \& Vasaitis, 2015). Fresh stumps cut at this time can be protected against Heterobasidion infection by treating them with biological (or chemical) control agents (Holdenrieder \& Greig, 1998; Thor, 2005). The biological control agent Rotstop ${ }^{\circledR}$ ('Rotstop F', Verdera Oy, Finland), composed of spores of the nonpathogenic wood-decay fungus Phlebiopsis gigantea (Fr.) Jülich, is used for stump protection also in Latvia, where its efficacy is similar to efficacy in other countries (Kenigsvalde et al., 2011; Kenigsvalde et al., 2016). However, research in Sweden has shown that sometimes native isolates of $P$. gigantea have higher efficacy than Rotstop, which contains a Finnish isolate of P. gigantea (Berglund et al., 2005). Moreover, large-scale use of a single genotype of fungus for a long time can negatively affect local populations of fungi in forest ecosystems (Vasiliauskas et al., 2004). Therefore, native isolates of $P$. gigantea can potentially be used for stump treatment in the future if the isolates provide similar or better protection compared to Rotstop.

The aim of our work was to compare the efficacy of Rotstop and nine Latvian $P$. gigantea isolates against different spore concentrations of Heterobasidion in stem pieces of spruce and pine.

\section{Materials and Methods \\ Field experiments}

Two experiments were carried out: Experiment 1 on 6th of July 2009, and Experiment 2 on 27th of October 2009. In each experiment two Norway spruce trees (Picea abies (L.) H. Karst.) and two Scots pine trees (Pinus sylvestris L.) were felled and cut into one meter long stem pieces. They were then transported to the site where experiments were carried 


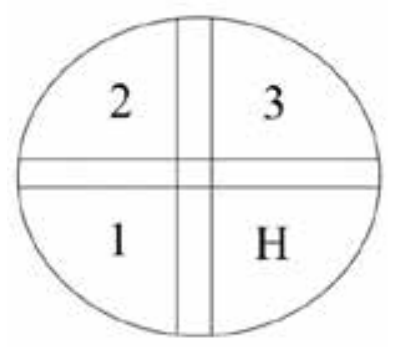

Figure 1. The cut surface of each billet was divided into four sectors and sprayed with two spore suspensions: a) $P$. gigantea suspension - asexual spores from one $P$. gigantea culture, b) Heterobasidion suspension mixture of asexual spores from one $H$. annosum and one $H$. parviporum culture. Sector treatments: $(\mathrm{H})$ Heterobasidion only, (1) P. gigantea and Heterobasidion, (2) P. gigantea and Heterobasidion two times; (3) P. gigantea and Heterobasidion three times.

out. Immediately before treatment, the stem pieces (diameter $13-16 \mathrm{~cm}$ ) were cut into ca. $30 \mathrm{~cm}$ long segments (billets), and the upper surface was divided into four sectors (Figure 1).

Four Latvian $P$. gigantea isolates were tested in field Experiment 1 and five isolates in greenhouse Experiment 2. The sectors 1-3 were first sprayed with an oidial suspension of a $P$. gigantea isolate. One hour later the whole cut surface was sprayed with a suspension of Heterobasidion conidiospores. After another hour, sectors 2 and 3 were again sprayed with Heterobasidion (same suspension as before), and after another hour, sector 3 was sprayed with Heterobasidion for the third time. During the treatment other sectors were covered with a paper sheet. An empty space of $2 \mathrm{~cm}$ width was left between sectors to avoid cross contamination. In both experiments, four replicate billets of spruce and four billets of pine were treated with each isolate of $P$. gigantea. The billets were placed on folded garden fabric to avoid contamination from soil, and incubated $3-4$ weeks outdoors (Experiment 1) or in a greenhouse (Experiment 2). Experiment 2 was conducted in a greenhouse, as weather conditions in October were not suitable for incubation outdoors. The billets were watered regularly to provide suitable moisture content in the billet for development of the fungi. Mean daily air temperature during incubation outdoors was $17^{\circ} \mathrm{C}$ (Experiment 1) and temperature during incubation in the greenhouse was $18{ }^{\circ} \mathrm{C}$ (Experiment 2) with

Table 1

\section{Some properties of the Latvian $P$. gigantea isolates cultivated on malt extract agar medium in Petri} dishes at room temperature

\begin{tabular}{|c|c|c|c|c|c|}
\hline \multirow[t]{2}{*}{$\begin{array}{l}\text { Isolate of } \\
\text { P. gigantea }\end{array}$} & \multirow[t]{2}{*}{ Host } & \multirow{2}{*}{$\begin{array}{l}\text { Growth rate on } \\
\text { agar medium, } \\
\text { mm day }^{-1}\end{array}$} & \multicolumn{2}{|c|}{$\begin{array}{l}\text { Growth rate over Heterobasidion colony } \\
\text { on agar medium, } \\
\text { mm day }{ }^{-1}\end{array}$} & \multirow{2}{*}{$\begin{array}{l}\text { Number of spores } \\
\text { produced in Petri } \\
\text { dish, millions }\end{array}$} \\
\hline & & & H. annosum & H. parviporum & \\
\hline $\mathrm{G} 1^{1}$ & $\begin{array}{l}\text { P. abies or } \\
\text { P. sylvestris }\end{array}$ & 7.1 & 0.9 & 1.4 & 47.3 \\
\hline $\mathrm{K} 4^{1}$ & P. abies & 8.6 & 0.9 & 1.2 & 21.5 \\
\hline $\mathrm{J} 4^{1}$ & P. sylvestris & 8.0 & 0.9 & 1.4 & 12.8 \\
\hline $\mathrm{T}_{207 \mathrm{E}^{1}}$ & P. abies & 6.5 & 0.7 & 0.7 & 182.8 \\
\hline $\mathrm{K} 107 \mathrm{P}^{2}$ & P. sylvestris & 5.9 & 0.6 & 0.7 & 22.2 \\
\hline $\mathrm{Kn}_{107 \mathrm{E}^{2}}$ & P. abies & 6.5 & 0.7 & 0.8 & 18.5 \\
\hline Le107E ${ }^{2}$ & P. abies & 6.1 & 0.6 & 0.8 & 23.7 \\
\hline Le 507P ${ }^{2}$ & P. sylvestris & 6.7 & 0.7 & 0.8 & 22.2 \\
\hline $\mathrm{J} 207 \mathrm{P}^{2}$ & P. sylvestris & 5.1 & 0.5 & 0.7 & 24.7 \\
\hline Mean & & 6.7 & 0.7 & 0.9 & 41.7 \\
\hline
\end{tabular}

${ }^{1}$ isolates used in Experiment 1

${ }^{2}$ isolates used in Experiment 2 
relative humidity $30 \%$. After incubation, four to six $2-3 \mathrm{~cm}$ thick sample discs were cut from the billets and transported to the laboratory.

\section{Analyses of the discs}

In the laboratory, the discs were debarked, washed with a stiff brush under running tap water, and incubated $5-7$ days in loosely closed plastic bags at room temperature. Both sides of the disc were examined. A grid consisting of $0.42 \mathrm{~cm}^{2}$ squares was fixed on each disc with pins. Each square was screened with a dissection microscope for the presence of Heterobasidion conidiophores, and the area, colonised by the fungus, was marked on the disc. Area colonised by $P$. gigantea was recognised on the basis of its typical orange brown colour in wood. The surface area occupied by Heterobasidion and by $P$. gigantea was redrawn on transparent paper and measured using a planimeter (PLANIX 10S 'Marble', Tamaya, Japan).

\section{Fungal isolates}

Four Latvian isolates of P. gigantea (G1, K4, J4, T207E) were used in Experiment 1 and five isolates (J207P, K107P, Kn107E, Le507P, Le107E) in Experiment 2. Rotstop was included in both experiments. The Latvian isolates had been previously tested in the laboratory for their growth rate on malt extract agar, production of asexual spores (oidia), and antagonistic ability against $H$. annosum and H. parviporum (Table 1), according to methods used by Sun et al. (2009a).

\section{Treatment suspensions}

Each $P$. gigantea isolate was cultured in several Petri dishes on malt extract agar medium for 3 weeks at ca. $20{ }^{\circ} \mathrm{C}$. Spore suspensions were prepared by washing the asexual spores several times from one Petri dish with tap water, agitating the colony gently with a Drigalski spatula. The spore suspension obtained from the Petri dish was filled to one liter and $0.5 \mathrm{~mL}$ were transferred and spread evenly on a Petri dish containing malt extract agar medium. After 24 hours, germinated spores of $P$. gigantea were counted under a microscope (magnification 100x) within 30 sight fields per dish. The number of spores per original Petri dish was calculated, taking into account the area of the sight field and the area of the Petri dish. Treatment suspensions were prepared 2-4 hours before the treatment of billets from a replicate Petri dish culture, and the spore concentration in suspension was adjusted to ca. 5000 spores $\mathrm{mL}^{-1}$. Suspension of Heterobasidion conidiospores was prepared as a mixture from one heterokaryotic H. parviporum (Rb175) and one H. annosum (358Rv) isolate originating from Sweden. Heterobasidion spore concentration in suspension was ca. 500 spores $\mathrm{mL}^{-1}$.

\section{Calculations and statistics}

Efficacy of $P$. gigantea treatment was calculated by comparing the area occupied by Heterobasidion on treated sectors of the disc (sapwood and heartwood included) to the area of Heterobasidion on the control (H) sector. The efficacy was calculated from depths 3 and $9 \mathrm{~cm}$ from billet surface, and the results were presented as means of the four billet replicates. The following formula was used to calculate the efficacy of different treatments:

$$
E(\%)=100-\left(100 * n_{t} / n_{u}\right),
$$

where $n_{t}$ and $n_{u}$ represent percentages of area occupied by Heterobasidion in treated and control sectors.

Control efficacy of $P$. gigantea and area occupied by both fungi were compared by the non-parametric Mann-Whitney test in RStudio (RStudio Team, 2015). Proportions were arcsine transformed before analyses.

\section{Results and Discussion}

Isolates of $P$. gigantea used in experiments were selected on the basis of previous tests in which the growth rate, spore production, and competitive ability against $H$. annosum and $H$. parviporum was measured in laboratory. Investigations by Sun et al. (2009a, 2009b) showed that efficacy of a P. gigantea isolate against Heterobasidion correlates mostly with its growth rate in wood. The growth rate of Latvian $P$. gigantea isolates on agar medium at room temperature varied from 5.1 to $8.6 \mathrm{~mm} \mathrm{day}^{-1}$. Within the material investigated by Sun et al. (2009a), consisting of $64 P$. gigantea isolates, the corresponding variation was from 3.8 to $10.8 \mathrm{~mm} \mathrm{day}^{-1}$. Abundant sporulation of a $P$. gigantea isolate is a useful property for easy manufacture of the preparation for practical stump treatment; the spore production of the nine Latvian isolates varied from 12.8 to 182.8 million spores per Petri dish. In the material investigated by Sun et al. (2009a) the range was from 2.0 to 271.6 million spores per Petri dish.

Considerable differences were noted in the colonisation of spruce wood by different $P$. gigantea isolates in Experiment 1 - area occupied by P. gigantea isolates varied from 5.0 to $58.8 \%$ at the level (depth of) $3 \mathrm{~cm}$ below billet surface, and from 0 to $50.8 \%$ at the level of $9 \mathrm{~cm}$. Comparable variation has been observed also in other investigations (Sun et al., 2009b; Berglund et al., 2005). As noted by other researchers (Webber \& Thorpe, 2003), P. gigantea colonises more effectively pine wood than spruce wood. In Experiment 1, the colonisation of pine wood by different $P$. gigantea isolates varied from 79.1 to 

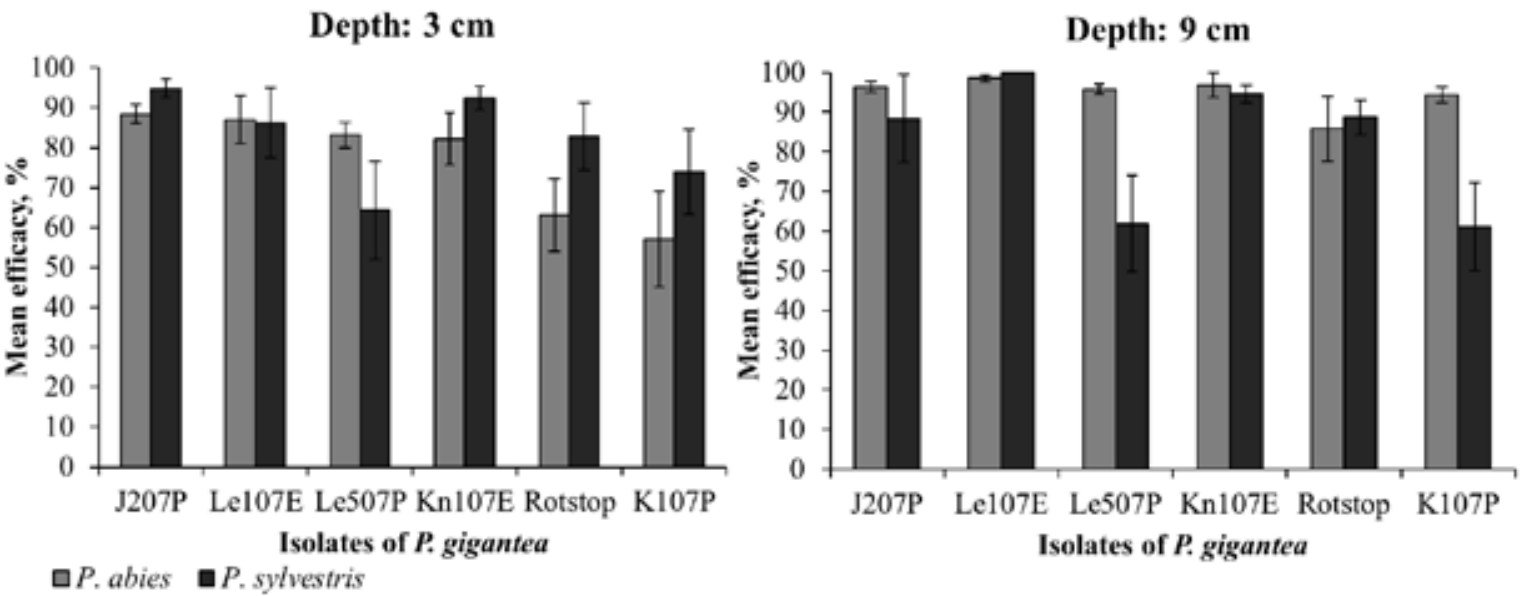

Figure 2. Mean efficacy of $P$. gigantea isolates in depth of 3 and $9 \mathrm{~cm}$ in billets (Experiment 2).

$89.9 \%$ at the depth of $3 \mathrm{~cm}$, and from 69.4 to $97.7 \%$ at the depth of $9 \mathrm{~cm}$.

In Experiment 1, started at the beginning of July and incubated in the field, mean control efficacy of Latvian isolates of $P$. gigantea in spruce wood at the depth of 3 and $9 \mathrm{~cm}$ from billet surface was $77 \%$ and $79 \%$, respectively. Corresponding values for the Rotstop isolate were $79 \%$ and $19 \%$. Berglund \& Rönnberg (2004) noted that the efficacy values of biological control agents were higher in the surface layers of a spruce stump, probably because Heterobasidion grows faster than $P$. gigantea in spruce wood (Holdenrieder \& Greig, 1998). It is possible that the Rotstop isolate did not reach the depth of $9 \mathrm{~cm}$ during the incubation time (Sun et al., 2009a) - mean area occupied by Rotstop isolate at the depth of $9 \mathrm{~cm}$ was $1 \%$, whereas the occupation of the four Latvian isolates varied from 6 to $35 \%$. In pine billets of Experiment 1 , the efficacy of all analysed $P$. gigantea isolates (including Rotstop) was $99-100 \%$, and the mean area occupied by $P$. gigantea in depths of 3 and $9 \mathrm{~cm}$ was $87 \%$ and $89 \%$.

In Experiment 2, started at the end of October and incubated in a greenhouse, Rotstop and $P$. gigantea isolate K107P had the lowest values of control efficacy and occupied area in depth of $3 \mathrm{~cm}$ in spruce billets (Figure 2 and Table 2).

In wood of spruce in depth of $9 \mathrm{~cm}$, there was no correlation between area occupied by $P$. gigantea and efficacy values although occupation of Rotstop and $P$. gigantea isolate $\mathrm{K} 107 \mathrm{P}$ were rather small compared with occupation of other isolates (Table 2).

$P$. gigantea isolates $\mathrm{K} 107 \mathrm{P}$ and Le507P had lowest efficacy values in wood of pine in depth of 9 $\mathrm{cm}: 61.1 \%$ and $61.8 \%$, respectively, despite the fact that the latter isolate had occupied a big part of wood $(68.7-82.3 \%)$ (Table 3$)$.

Calculations of control efficacy of $P$. gigantea against Heterobasidion can be based on two kinds of data: the number of stumps infected by Heterobasidion,

Area occupied by $P$. gigantea on sample discs cut from spruce billets (Experiment 2)

\begin{tabular}{|c|c|c|c|c|c|c|}
\hline \multirow{2}{*}{$\begin{array}{c}\text { Number of treatments } \\
\text { with Heterobasidion spore } \\
\text { suspension }(500 \text { spores } \\
\left.\mathrm{mL}^{-1}\right)\end{array}$} & \multicolumn{6}{|c|}{ Area occupied by isolates of $P$. gigantea, $\%$ from total sector area } \\
\hline & $\mathrm{J} 207 \mathrm{P}$ & Le107E & Le507P & $\mathrm{Kn} 107 \mathrm{E}$ & Rotstop & K107P \\
\hline \multicolumn{7}{|l|}{ analysed depth: $3 \mathrm{~cm}$} \\
\hline 1 & $14.2 \pm 7.5$ & $29.7 \pm 15.9$ & $31.0 \pm 12.6$ & $40.4 \pm 15.2$ & $8.4 \pm 1.4$ & 0.0 \\
\hline 2 & $29.5 \pm 4.2$ & $20.5 \pm 4.3$ & $37.8 \pm 14.9$ & $49.6 \pm 7.6$ & $17.9 \pm 8.6$ & $0.5 \pm 0.5$ \\
\hline 3 & $33.0 \pm 8.7$ & $22.8 \pm 7.9$ & $37.7 \pm 13.3$ & $48.6 \pm 12.4$ & $25.4 \pm 6.4$ & $0.3 \pm 0.3$ \\
\hline \multicolumn{7}{|l|}{ analysed depth: $9 \mathrm{~cm}$} \\
\hline 1 & $17.9 \pm 12.2$ & $21.5 \pm 9.2$ & $28.3 \pm 14.6$ & $44.8 \pm 13.5$ & $7.3 \pm 2.4$ & 0.0 \\
\hline 2 & $22.7 \pm 9.7$ & $21.7 \pm 12.0$ & $36.5 \pm 10.0$ & $46.4 \pm 12.8$ & $5.1 \pm 3.8$ & $8.7 \pm 8.7$ \\
\hline 3 & $9.3 \pm 5.5$ & $21.3 \pm 12.6$ & $28.0 \pm 11.3$ & $33.3 \pm 6.0$ & $3.7 \pm 2.1$ & $2.3 \pm 1.5$ \\
\hline
\end{tabular}




\section{Area occupied by $P$. gigantea on sample discs cut from pine billets (Experiment 2)}

\begin{tabular}{|c|c|c|c|c|c|c|}
\hline \multirow{2}{*}{$\begin{array}{c}\text { Number of treatments } \\
\text { with Heterobasidion spore } \\
\text { suspension (500 spores } \\
\left.\mathrm{mL}^{-1}\right)\end{array}$} & \multicolumn{6}{|c|}{ Area occupied by isolates of $P$. gigantea, $\%$ from total sector area } \\
\hline & $\mathrm{J} 207 \mathrm{P}$ & Le107E & Le507P & Kn107E & Rotstop & K107P \\
\hline \multicolumn{7}{|l|}{ analysed depth: $3 \mathrm{~cm}$} \\
\hline 1 & $85.6 \pm 3.6$ & $80.7 \pm 4.4$ & $84.4 \pm 1.5$ & $86.3 \pm 1.6$ & $84.8 \pm 2.3$ & $63.7 \pm 17.1$ \\
\hline 2 & $88.7 \pm 3.8$ & $87.9 \pm 2.9$ & $88.9 \pm 1.1$ & $94.0 \pm 0.6$ & $85.3 \pm 2.9$ & $67.2 \pm 9.7$ \\
\hline 3 & $91.8 \pm 2.9$ & $91.4 \pm 3.7$ & $88.6 \pm 1.4$ & $90.0 \pm 2.1$ & $86.3 \pm 0.7$ & $91.0 \pm 1.7$ \\
\hline \multicolumn{7}{|l|}{ analysed depth: $9 \mathrm{~cm}$} \\
\hline 1 & $55.4 \pm 17.1$ & $80.2 \pm 2.8$ & $82.3 \pm 1.6$ & $71.1 \pm 4.6$ & $53.8 \pm 17.4$ & $41.4 \pm 15.5$ \\
\hline 2 & $54.0 \pm 13.3$ & $78.4 \pm 5.1$ & $80.1 \pm 3.6$ & $65.8 \pm 21.1$ & $51.2 \pm 17.6$ & $45.7 \pm 13.7$ \\
\hline 3 & $57.3 \pm 11.7$ & $81.6 \pm 7.6$ & $68.7 \pm 9.2$ & $60.2 \pm 15.3$ & $47.7 \pm 16.7$ & $46.4 \pm 14.3$ \\
\hline
\end{tabular}

or wood area colonised by it in stumps (Kenigsvalde et al., 2016). The results obtained with these two methods can differ more than two times (Thor \& Stenlid, 2005). We consider that occupied area is a better indicator of control efficacy of a $P$. gigantea isolate, because infection frequency of stumps can be affected by stump size and amount of spores in the stand (Redfern \& Stenlid, 1998).

Efficacy of $P$. gigantea isolates is affected by properties of wood and isolates (Berglund et al., 2005). In some earlier investigations Rotstop was shown to have higher values of efficacy in spruce (Korhonen et al., 1994; Korhonen, 2003) than in the experiments presented above. It is possible that Latvian isolates of $P$. gigantea are more adapted to local conditions. Also in Sweden, Rotstop showed lower efficacy values compared to native isolates of $P$. gigantea (Berglund $e t$ al., 2005). However, in Experiments 1 and 2 in depths of 3 and $9 \mathrm{~cm}$, mean efficacy values of Rotstop (mean from all analysed sectors) in spruce $(61.5 \%)$ and pine $(90.5 \%)$ were rather similar to values obtained in previous investigations conducted in Latvia: $89 \%$ in spruce and $95 \%$ in pine - efficacy values calculated based on wood occupied by Heterobasidion (Kenigsvalde et al., 2016). Mean efficacy of Latvian isolates of $P$. gigantea in Experiments 1 and 2 in depths of 3 and $9 \mathrm{~cm}$ (mean from all analysed sectors) was $83.6 \%$ in spruce and $88.7 \%$ in pine.

In our experiments, the efficacy of $P$. gigantea isolates was not affected by increasing number of Heterobasidion spores applied to billet surface. Meredith (1960) and Rishbeth (1963) found that if the spores of Heterobasidion and P. gigantea are mixed together in one suspension, then even a low concentration of $P$. gigantea spores can significantly reduce the development of Heterobasidion. Moisture content of wood is very significant for the growth of Heterobasidion and $P$. gigantea in wood (Redfern, 1993; Sun et al., 2009a). In our experiments, one sector on the billet surface was treated twice and one three times with Heterobasidion spore suspension. Together with higher number of spores, more water was applied to these sectors. Increased moisture content of wood may have inhibited the development of Heterobasidion in these sectors. In the greenhouse Experiment 2, surprisingly, $P$. gigantea isolates showed lower values of colonisation and efficacy in pine than in spruce, especially in depth of $9 \mathrm{~cm}$ (Table 3). A possible explanation is the absence of wind in greenhouse; it slows down or even prevents the drying of billet surface. This may have, for example, favoured the growth of mould in wood, and affected the interaction between Heterobasidion and $P$. gigantea more in pine than in spruce billets.

\section{Conclusions}

1. Efficacy of biological control agent Rotstop against Heterobasidion spp. was $61 \%$ in spruce and $90 \%$ in pine.

2. Latvian isolates of $P$. gigantea showed similar ( $89 \%$ in pine) or even higher values $(84 \%$ in spruce) of efficacy against Heterobasidion spp. comparing to the Rotstop isolate.

3. Latvian isolates of $P$. gigantea Le107E and Kn107E can potentially be used for preparation of a biological control agent in the future.

\section{Acknowledgements}

In accordance with the contract No. 1.2.1.1/16/A/009 between 'Forest Sector Competence Centre' Ltd. and the Central Finance and Contracting Agency, concluded on October 13, 2016, the study is conducted by the Latvian State Forest Research 
Institute 'Silava' with support from the European Regional Development Fund (ERDF) within the framework of the project 'Forest Sector Competence Centre'.
This study was also supported by State Research Programme, JSC 'Latvia's State Forests'. We express our gratitude to Kari Korhonen for valuable suggestions and Guntis Brūmelis for language revision.

\section{References}

1. Bendz-Hellgren, M., Lipponen, K., Solheim, H., \& Thomsen, I.M. (1998). Impact, control and management of Heterobasidion annosum root and butt rot in Europe and North America. The Nordic Countries. In S. Woodward, J. Stenlid, R. Karjalainen, \& A. Hüttermann (Eds.), Heterobasidion annosum: Biology, Ecology, Impact and Control (pp. 333 - 345). Wallingford, UK: CAB International.

2. Berglund, M., \& Rönnberg, J. (2004). Effectiveness of treatment of Norway spruce stumps with Phlebiopsis gigantea at different rates of coverage for the control of Heterobasidion. For. Path. 34(4), 233 - 243. DOI: 10.1111/j.1439-0329.2004.00363.x.

3. Berglund, M., Rönnberg, J., Holmer, L., \& Stenlid, J. (2005). Comparison of five strains of Phlebiopsis gigantea and two Trichoderma formulations for treatment against natural Heterobasidion spore infections on Norway spruce stumps. Scand. J. For. Res. 20(1), 12 - 17. DOI: 10.1080/02827580510008202.

4. Brandtberg, P.-O., Johansson, M., \& Seeger, P. (1996). Effects of season and urea treatment on infection of stumps of Picea abies by Heterobasidion annosum in stands on former agricultural land. Scand. J. For. Res. 11(1-4), 261 - 268. DOI: 10.1080/02827589609382935.

5. Brūna, L., Gaitnieks, T., \& Vasaitis, R. (2015). Spore production of Heterobasidion annosum s.l. fruit bodies in Latvia: impact of seasonal and meteorological factors. In Adaptation and Mitigation: Strategies for Management of Forest Ecosystems, 23 - 24 April 2015 (pp. 37). Salaspils: LSFRI Silava.

6. Gaitnieks, T., Arhipova, N., Donis, J., Stenlid, J., \& Vasaitis, R. (2008). Butt rot incidence and related losses in Latvian Picea abies (L.) Karst. stands. In Proceedings of the $12^{\text {th }}$ International IUFRO Conference on Root and Butt Rots of Forest Trees, 12 - 19 August 2007 (pp. 177 - 179). Berkeley, USA: The University of California.

7. Holdenrieder, O., \& Greig, B.J.W. (1998). Biological methods of control. In S. Woodward, J. Stenlid, R. Karjalainen, \& A. Hüttermann (Eds.), Heterobasidion annosum: Biology, Ecology, Impact and Control (pp. 235 - 258). Wallingford, UK: CAB International.

8. Jansons, J. (2014). Latvijas meža resursu statistiskā inventarizācija. Latvijas meža resursu statistiskās inventarizācijas II cikla rezultāti (Statistical inventory of resources of forests of Latvia: results of cycle II). Retrieved February 24, 2017, from: http://www.silava.lv/petijumi/nacionlais-mea-monitorings.aspx (in Latvian).

9. Kallio, T. (1970). Aerial distribution of the root-rot fungus Fomes annosus (Fr.) Cooke in Finland. Acta For. Fenn. 107, 55 pp.

10. Kenigsvalde, K., Donis, J., Korhonen, K., \& Gaitnieks, T. (2011). Phlebiopsis gigantea skujkoku celmu biologiskajā aizsardzībā pret Heterobasidion annosum s.l. izraisīto sakṇu trupi-literatūras apskats (Biological control of Heterobasidion root rot of coniferous stumps by Phlebiopsis gigantea-literature review). Mežzin. 23: 25 - 40. (in Latvian).

11. Kenigsvalde, K., Brauners, I., Korhonen, K., Zaļuma, A., Mihailova, A., \& Gaitnieks, T. (2016). Evaluation of the biological control agent Rotstop in controlling the infection of spruce and pine stumps by Heterobasidion in Latvia. Scand. J. For. Res. 31(3), 254 - 261. DOI: 10.1080/02827581.2015.1085081.

12. Korhonen, K., Liponen, K., Bendz, M., Johansson, M., Ryen, I., Venn, K., Seiskari, P., \& Niemi, M. (1994). Control of Heterobasidion annosum by stump treatment with 'Rotstop', a new commercial formulation of Phlebiopsis gigantea. In Proceedings of the 8th IUFRO Conference on Root and Butt Rots, 9 - 16 August 1993 (pp. 675 - 685). Uppsala, Sweden: Swedish University of Agricultural Sciences.

13. Korhonen, K. (2003). Simulated stump treatment experiments for monitoring the efficacy of Phlebiopsis gigantea against Heterobasidion. In Proceedings of the 10th IUFRO Conference on Root and Butt Rots of Forest Trees, 16 - 22 September 2001 (pp. 206 - 210). Quebec, Canada: Laurentian Forestry Centre.

14. Korhonen, K., \& Holdenrieder, O. (2005). Neue Erkenntnisse über den Wurzelschwamm (Heterobasidion annosum s.1.). Eine Literaturübersicht (Recent advances in research on the root rot fungus Heterobasidion annosum s.1. A literature review). Forst und Holz. 60(5), 206 - 211. (in German).

15. Meredith, D.S. (1960). Further observations on fungi inhabiting pine stumps. Ann. Bot. 24(1), $63-79$. DOI: 10.1093/oxfordjournals.aob.a083689.

16. RStudio Team (2015). RStudio: Integrated Development for R [computer software]. Boston, MA: RStudio, Inc. Retrieved February 24, 2017, from: http://www.rstudio.com/. 
17. Redfern, D.B. (1993). The effect of wood moisture on infection of Sitka spruce stumps by basidiospores of Heterobasidion annosum. Eur. J. For. Pathol. 23(4), 218 -235. DOI: 10.1111/j.1439-0329.1993.tb01340.x.

18. Redfern, D.B., \& Stenlid, J. (1998). Spore dispersal and infection. In S. Woodward, J. Stenlid, R. Karjalainen, \& A. Hütermann (Eds.), Heterobasidion annosum: Biology, Ecology, Impact and Control (pp. 109 - 116). Wallingford, UK: CAB International.

19. Rishbeth, J. (1963). Stump protection against Fomes annosus. III. Inoculation with Peniophora gigantea. Ann. Appl. Biol. 52(1), 63 - 77. DOI: 10.1111/j.1744-7348.1963.tb03728.x.

20. Stenlid, J., \& Redfern, D.B. (1998). Spread within the tree and stand. In S. Woodward, J. Stenlid, R. Karjalainen, \& A. Hütermann (Eds.), Heterobasidion annosum: Biology, Ecology, Impact and Control (pp. 125 - 141). Wallingford, UK: CAB International.

21. Sun, H., Korhonen, K., Hantula, J., \& Kasanen, R. (2009a). Variation in properties of Phlebiopsis gigantea related to biocontrol against infection by Heterobasidion spp. in Norway spruce stumps. For. Path. 39(2), 133 - 144. DOI: 10.1111/j.1439-0329.2008.00574.x.

22. Sun, H., Korhonen, K., Hantula, J., Asiegbu, F.O., \& Kasanen, R. (2009b). Use of a breeding approach for improving biocontrol efficacy of Phlebiopsis gigantea strains against Heterobasidion infection of Norway spruce stumps. FEMS Microb. Ecol. 69(2), 266 - 273. DOI: 10.1111/j.1574-6941.2009.00711.x.

23. Thor, M. (2005). Heterobasidion root rot in Norway spruce. Modelling incidence, control efficacy and economic consequences in Swedish forestry. Doctoral dissertation, Swedish University of Agricultural Sciences, Uppsala, Sweden.

24. Thor, M., \& Stenlid, J. (2005). Heterobasidion annosum infection of Picea abies following manual or mechanized stump treatment. Scand. J. For. Res. 20(2), 154 - 164. DOI: 10.1080/02827580510008338.

25. Vasiliauskas, R., Lygis, V., Thor, M., \& Stenlid, J. (2004). Impact of biological (Rotstop ${ }^{\circledR}$ ) and chemical (urea) treatments on fungal community structure in freshly cut Picea abies stumps. Biol. Contr. 31(3), 405 - 413. DOI: 10.1016/j.biocontrol.2004.05.006.

26. Webber, J., \& Thorpe, K. (2003). Potential for biological control of Heterobasidion annosum in the UK using Rotstop. In Proceedings of the 10th IUFRO Conference on Root and Butt Rots of Forest Trees, $16-$ 22 September 2001 (pp. 221 - 225). Ottawa, Canada: Canadian Forest Service.

27. Yde-Andersen, A. (1962). Seasonal incidence of stump infection in Norway spruce by air-borne Fomes annosus spores. For. Sci. 8(2), $98-103$.

28. Василяускас, А. (1989). Корневая губка $u$ устойчивость экосистем хвойных лесов. (Root fungus and resistance of coniferous forests' ecosystems). Vilnius: Mokslas. (in Russian). 